\title{
Analysis of socio-demographic prerequisites for the formation of the region's human resources
}

\author{
Maria Pikushina \\ Federal State Budgetary Educational Institution of Higher \\ Education "Ryazan State Agrotechnological University \\ Named after P.A. Kostychev", \\ Institute of Economics and Finance \\ Department of Economics and Management \\ Ryazan, Russia \\ uhanovamu@mail.ru
}

\author{
Alexander Shemyakin \\ Federal State Budgetary Educational Institution of Higher \\ Education "Ryazan State Agrotechnological University \\ Named after P.A. Kostychev", \\ Department of Road Transport \\ Ryazan, Russia \\ shem.alex62@yandex.ru
}

\author{
Ivan Babkin \\ Peter the Great Saint-Petersburg Polytechnic University \\ Institute of Industrial Management, Economics and Trade \\ St. Petersburg, Russia \\ ivan.babkin@spbstu.ru
}

\begin{abstract}
In modern conditions the labor potential, its quantitative and qualitative characteristics become the decisive strategic factor for the sustainable development of the territories. The purpose of the study was to determine the impact of sociodemographic conditions on the formation of human resources as the main factor of sustainable development of the region. The analysis was carried out on the basis of relative statistical parameters calculated by periods of crisis range in the national economy. It was found that the positive balance of labor resources was achieved due to external influx, with a significant internal outflow of the most qualified part of the labor force to regions with higher social development indicators. By natural movement of the population there is a reduction in the rate of natural loss, but no positive balance was reached. The indicators of natural movement were not related to the nature of crises in the national economy, which confirms the effectiveness of the demographic development strategy. Indicators of the standard of living of the population are more significant than the demographic indicators in reflecting the crises range in the crisis periods. The crisis of $\mathbf{2 0 1 4}$ did not practically have any impact on employment indicators in contrast to the income indicators of the population, whose growth rate by 2015 was lower than $100 \%$. Based on the analysis, prospective trends in the formation of socio-demographic conditions for sustainable development of the region were identified.
\end{abstract}

Keywords - migration, natural change, human resources, sustainable development, crises range, comparative figures

\section{INTRODUCTION}

In modern conditions it is the labor potential, its quantitative and qualitative characteristics that become the decisive strategic factor for sustainable development of the territories, increasing the economic efficiency of agricultural production and ensuring the country's food security. Therefore many regions independently allocate formation of personnel potential as the main factor of development strategy. The purpose of the study was to determine the impact of sociodemographic conditions on the formation of human resources as the main factor of sustainable development of the region.

\section{MATERIALS AND METHODS (MODEL)}

When analyzing sustainable development of the region and the personnel prerequisites for economic modernization, the methodology developed by the organization for economic cooperation and development was used. The typological grouping of sustainable development factors was carried out according to generally accepted groups of social, economic and environmental indicators. The same factors are traditionally identified for the assessment of the prerequisites for the formation of human resources. However, in the study we conducted not absolute indicators in each group, but their rates of growth were taken as the basics. This made possible not only to take into account the dynamic characteristics of growth indicators, but also to assess the possibility of adjusting strategic plans, both on the basis of trends in indicators and their range, expressed in chain growth rates. 
To evaluate the dynamics of formation indicators as markers, 2006, 2009 and 2014 were adopted as the periods of the crisis and post-crisis state of the regional economic system. Undoubtedly, the greatest influence on the formation of human labor and human resources is provided by demographic factors, a detailed analysis of which is presented in this paper. Calculations were carried out on materials of Ryazan oblast [2].

\section{RESULTS AND DISCUSSION}

Analysis of the demographic situation in Ryazan oblast characterized the slowdown in the regional population decline (Figure 1). At the same time in 2015 there was a decrease in the rate of reduction. So in 2015 as compared to 2006, the rate of population decline in the region was $4.5 \%$, and compared to $2014-0.5 \%$.

This is explained by state support measures in the sphere of natural movement of the population and changes in migration policy.

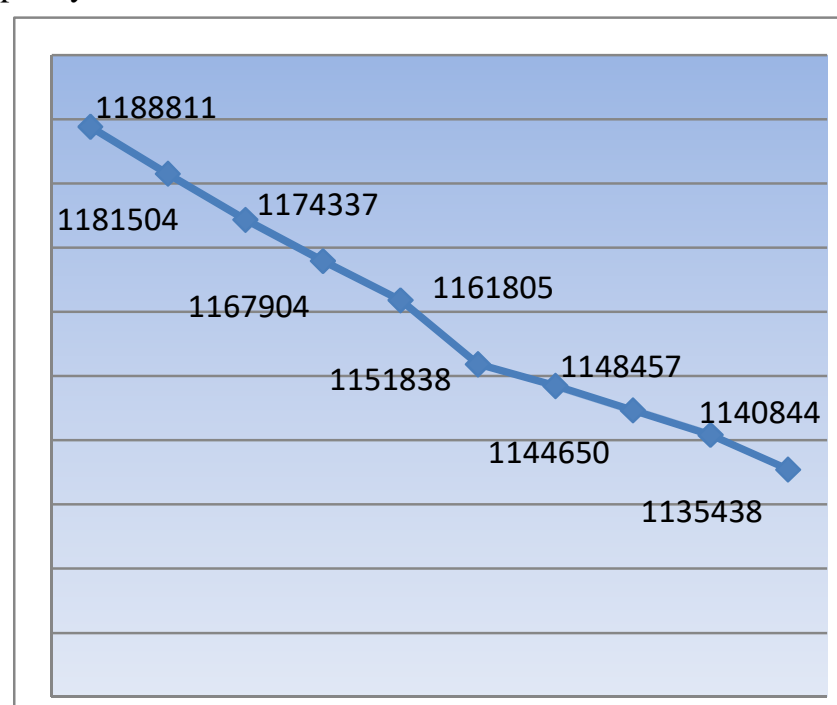

2006200720082009201020112012201320142015

Figure 1 - Dynamics of Ryazan oblast population, thousand persons.

The dynamics of indicators of the natural movement of the population (Figure 2) shows that the periods of the crisis did not cause serious changes in the formed trends of direct and indirect indicators. From 2013, there is a slowdown in the growth rate of the birth rate, with constant chain increases in the mortality rate, which has led to some growth in the natural decline in the population, but the periods of these changes do not coincide with the periods of the economic crisis and are caused by the social development gap (insufficient availability of medical institutions, pre-school education institutions, etc.).

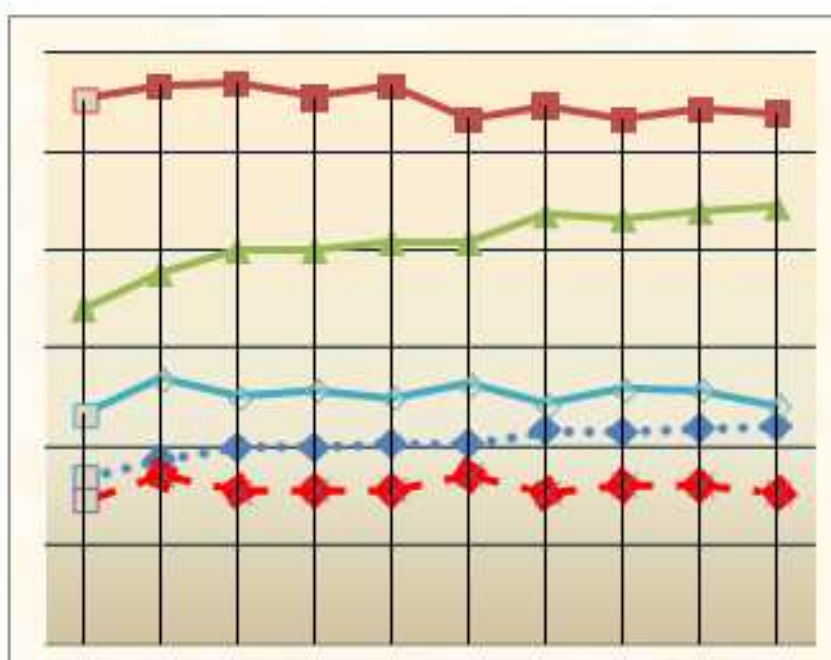

2006200720082009201020112012201320142015

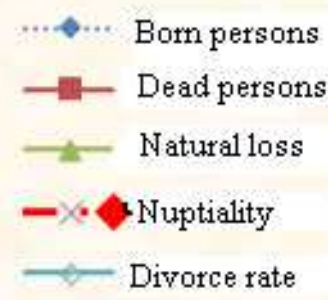

Figure 2 - Dynamics of parameters of natural movement of Ryazan oblast population

Changes of parameters of the population natural movement indicate that they practically did not react to the impact of the crisis phenomena, in contrast to parameters of migration processes (Figure 3). The positive balance of migration was observed throughout the analyzed period, however, during the crisis of 2009-2010 and especially in 2014 there was a significant decrease in it, characterized by a considerable internal outflow of the population.

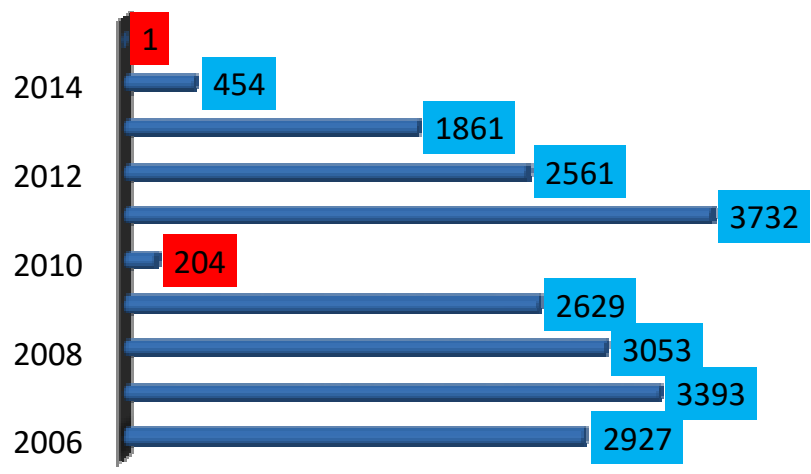

Figure 3 - Dynamics of parameters of migration in Ryazan oblast 
The positive significance of migration growth is due to labor migration from the countries of the former CIS. The citizens of Uzbekistan and the Republic of Moldova prevail in the structure of arrived labor migrants. In 2015 the share of migrants from Ukraine increased and amounted to $21.2 \%$. If we consider the dynamics of migration flows only within Russia, then it is possible to observe the excess of the number of people who left over the number of people who came to the region for almost the entire analyzed period. This situation is largely due to the territorial proximity of Moscow oblast, the region, where the calculated average monthly wage exceeds the national average. This leads to "pumping out" the most educated and professional personnel and reduces the personnel potential of Ryazan oblast [1].

The indicators of the standard of living of the population (Figure 4) are more significantly than demographic parameters reflect fluctuations in crisis periods. The crisis of 2014 did not practically affect the employment indicators, in contrast to the income indicators of the population, the growth rate of which by 2015 fell below the $100 \%$ mark.

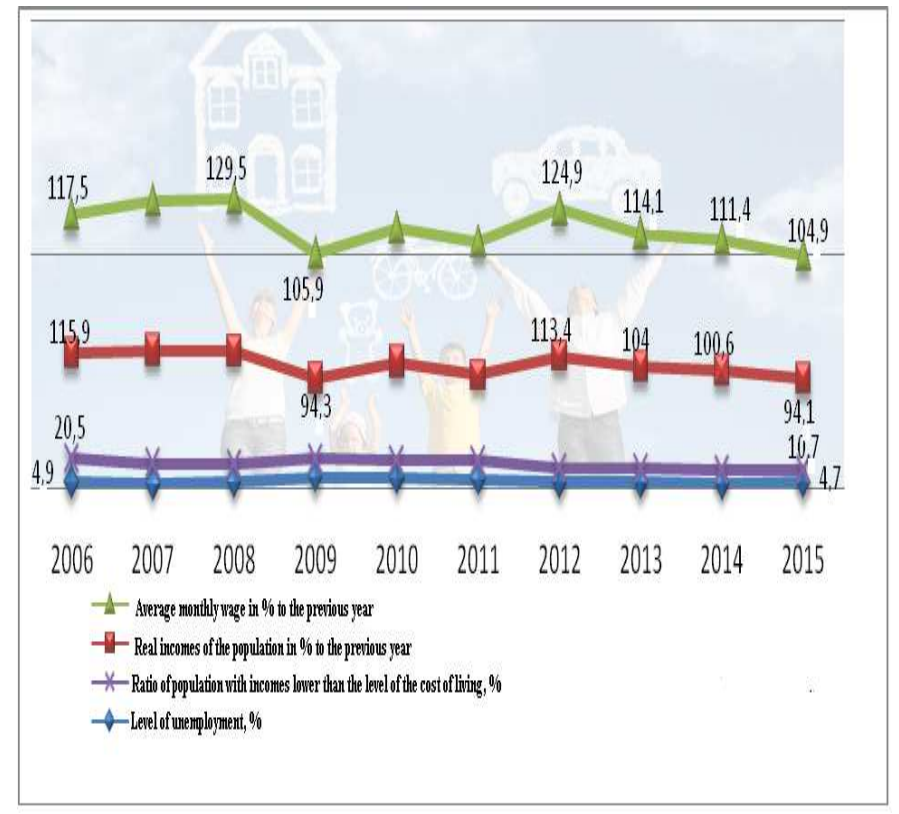

Figure 4 - Dynamics of parameters of Ryazan oblast population level of living

Much attention in recent years has also been paid to gender inequality in the formation of labor potential. Despite the visible shift towards the vague boundaries of gender differences, the difference in pay and positions held by representatives of different types remains significant. The wages of women in Ryazan oblast are $63 \%$ of the wages level of men (for comparison, the average for Russia exceeds $74 \%$ ). This situation is due not only to traditional economic activities, but also to positions that are on average lower in rank for women than for men.

Socio-demographic conditions for the formation of the labor market in Ryazan oblast had an impact on both the number of people employed in the economy and the distribution of labor resources by types of economic activity [3].

Table 1 - Dynamics of employed people in Ryazan oblast (by calculations of the balance of labor resources)

\begin{tabular}{|c|c|c|c|c|c|}
\hline Parameters & \multicolumn{2}{|c|}{ Chain growth rate, \% } & \multicolumn{2}{c|}{ Growth rate in 2015, \% } \\
\cline { 2 - 6 } & $\mathbf{2 0 0 6}$ & $\mathbf{2 0 0 9}$ & $\mathbf{2 0 1 4}$ & $\begin{array}{c}\text { chain } \\
\text { (in 2014) }\end{array}$ & $\begin{array}{c}\text { basic } \\
\text { (in 2006) }\end{array}$ \\
\hline $\begin{array}{c}\text { Total number of } \\
\text { employees in } \\
\text { the economy }\end{array}$ & -1.0 & -3.4 & -1.3 & +2.2 & -3.0 \\
\hline $\begin{array}{c}\text { Number of } \\
\text { people } \\
\text { employed by } \\
\text { type of activity } \\
\text { "Agriculture, } \\
\text { hunting, } \\
\text { forestry" }\end{array}$ & -3.8 & -4.2 & -2.5 & -40.6 & -57.7 \\
\hline
\end{tabular}

The dynamics of the number of employed in Ryazan oblast shows a steady trend of not a significant decline, without considerable fluctuations in the years of crisis. In 2015 there was an insignificant increase of $2.2 \%$ as compared to 2014. At the same time, a catastrophic situation is observed in the provision of labor resources in the agricultural sector. Thus, the decline in the number of employed in agriculture in 2015 was more than $40 \%$ as compared to 2014 and the reduction exceeded $50 \%$ as compared to 2006. The decrease in the share of people employed in agriculture and forestry is shown in Figure 5.

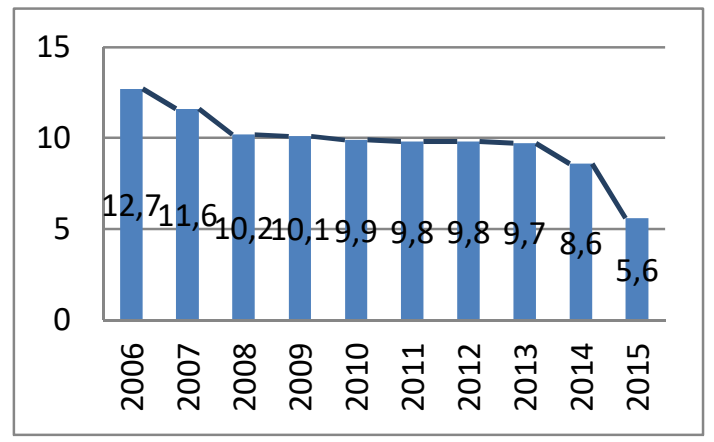

Figure 5 - Dynamics of the share employed in agriculture of Ryazan oblast, \%

\section{CONCLUSION}

Based on the analysis of socio-demographic conditions for the formation of human resources, the following conclusions can be drawn:

- the main deterrent to maintaining the human resources capacity of the region is low standard of living of the population. To overcome the current situation, first of all, it is necessary to reduce the level of differentiation of regions in terms of labor remuneration, which will help to restrain the 
outflow of the most qualified personnel in the process of internal migration;

- smoothing negative trends in evaluating demographic processes requires improving the quality of social services for the population on the basis of a detailed analysis of the sphere of social services for the population and identification of existing problems, the development of a regulatory and legal framework regulating relations in the sphere of social services;

- the most difficult situation has arisen in the formation of the human resource potential of the regional rural areas. In this industry, first of all, it is necessary to take targeted measures to introduce labor-saving innovative technologies, create favorable conditions for overcoming depopulation in the countryside, reduce the death rate of workers of working age, sharply increase housing construction for agricultural workers, and improve the system of training and improving the skills of agricultural workers.

\section{References}

[1] Kuzina, E.I. Labor potential of rural territories, its formation and regulation: synopsis of a Candidate of Economic Science thesis. - M.: All-Russian Research Institute of Agricultural Economics of the Russian Academy of Agricultural Science, 2012

[2] Pikushina, M.Yu., Otto, V.S., Somova, T.Yu. Practical aspects of realizing the principles of strategic planning on the regional level // School of the future. No. 1. 2015. P. 155-165.

[3] Pikushina, M.Yu. Methodological approaches to evaluation of human resources // Collection: Development of economic analysis and its role in conditions of transforming market economy: Materials of All-Russian science and practice conference dedicated to 10 years of the department of economic analysis and statistics, RSATU Named after P.A. Kostychev, 2008. P. 212-215.

[4] Babkin I. A.; Yuschenko A. L.; Babkina O. M. Vertical training system as the basis for the development of regional business systems // 2017 IEEE VI Forum Strategic Partnership of Universities and Enterprises of Hi-Tech Branches (Science. Education. Innovations) (SPUE), Pages: $181-184$ 